\title{
NAUCZANIE RELIGII W SZKOLE WOBEC RZECZYWISTOŚCI CYFROWEJ
}

Kilka miesięcy temu wszyscy nauczyciele, $w$ tym nauczyciele religii, znaleźli się w zaskakującym położeniu. Tak tę sytuację na gorąco analizuje jeden z nich: „I oto stało się! W kalendarzu jest marzec 2020. We wszystkich tytułach «koronawirus»! «Jeszcze nigdy nie widzieliśmy czegoś podobnego» (Mk 2,12b), możemy powtórzyć za mieszkańcami Kafarnaum. Nowa niełatwa rzeczywistość i niezwykle trudne doświadczenie naszego czasu. Ale z drugiej strony może to jest okazja, aby zbliżyć się do siebie, pomimo tego, że trzeba przestrzegać rozporządzenia o zakazie zgromadzeń? Trzeba jakoś funkcjonować, ale najlepiej tak, żeby potem opowiedzieć, że to trudne doświadczenie zbliżyło ludzi do siebie"1. Nagła, nieoczekiwana rewolucja edukacyjna związana z koniecznością zorganizowania nauczania zdalnego wymagała od wszystkich, począwszy od uczniów, poprzez rodziców, nauczycieli, dyrektorów szkół, aż po władze samorządowe i administrację rządową niestandardowego działania i przestawienia się ze znanych i utartych kolein w stronę rozwiązań nowatorskich i nieznanych. Z punktu widzenia psychologicznego w zaistniałych okolicznościach zaobserwować można symptomy kryzysu, takie jak: zaskoczenie, budzenie silnych emocji, dezorganizacja codziennego życia czy uruchomienie mechanizmów obronnych ${ }^{2}$.

Jak każdy kryzys, tak i ten, obok trudności, które są jego konsekwencją, jest i pewnego rodzaju szansą, okazją do zmiany przyzwyczajeń i strategii, także edukacyjnych. Jak nadmienił odnośnie do obecnego pandemicznego kontekstu biskup Galbas: „To wszystko wymaga jednak odwagi przekraczania schematów, pomysłowości i uniezależnienia się od stereotypów zawartych w dwóch fatalnych zdaniach, często obecnych w praktyce duszpasterskiej Kościoła w Polsce: «zawsze tak było»

\footnotetext{
1 Mariusz Śliwa, E-katecheza? Zdalna katecheza w czasach \#zostańcie w domu, w: https://przemyska. pl/2020/03/19/katecheza-on-line/ [plik do pobrania, dostęp: 25.09.2020].

2 Zob. W. Poleszak, J. Pyżalski, Psychologiczna sytuacja dzieci i młodzieży w dobie pandemii, w: Edukacja w czasach pandemii wirusa COVID-19. Z dystansem o tym, co robimy obecnie jako nauczyciele, red. J. Pyżalski, Warszawa 2020, s. 7.
} 
oraz «nigdy tak nie było!»”3. Powyższe słowa dobrze korespondują z zachętą papieża Franciszka, aby rezygnować: „Z wygodnego kryterium, że «zawsze się tak robiło». Zachęcam wszystkich, by byli odważni i kreatywni w tym zadaniu przemyślenia celów, stylu i metod ewangelizacyjnych swojej wspólnoty"4.

$\mathrm{Na}$ dokonanie oceny zmian, które staną się konsekwencją trwającej jeszcze pandemii, jest niewątpliwie za wcześnie, ale to, co już widać, to między innymi konieczność sięgnięcia przez nauczycieli religii, pracujących zarówno z dziećmi, jak i z młodzieżą, w większym niż dotychczas stopniu po formy i metody pracy związane z technologiami cyfrowymi. Dla wielu nauczycieli, zwłaszcza starszych, jest to czas swoistej rewolucji technologicznej, przed którą może wcześniej dosyć konsekwentnie się bronili, dla innych, którzy i dotychczas korzystali w swojej pracy $\mathrm{z}$ technologii cyfrowych, jest to czas utwierdzenia w przekonaniu, że wcześniej podejmowane wysiłki były dobre i teraz przynoszą owoce. Swoistą zachętą do podejmowania wysiłku sięgania po kreatywne sposoby pracy z uczniami, również w sytuacji konieczności nauczania na odległość, a także przewodnikiem ukazującym pewne zasady i prawidłowości związane z włączaniem rzeczywistości cyfrowej w nauczanie jest ogłoszone niedawno nowe Dyrektorium o katechizacji ${ }^{5}$, które ze zrozumiałych względów poświęca tej kwestii dużo więcej uwagi niż wcześniejszy dokument, powstały 23 lata temu' ${ }^{6}$.

Nowy dokument katechetyczny, mówiąc o katechezie w różnych kontekstach społeczno-kulturalnych, sporo miejsca poświęca właśnie kulturze cyfrowej ${ }^{7}$. Pierwszym wnioskiem z analizy obecnej sytuacji jest myśl, że cyfrowość nie jest dzisiaj jedynie elementem, mniej lub bardziej obecnym w kulturze, ale że stanowi nową kulturę, zmieniającą język, kształtującą mentalność, a także wprowadzającą nową hierarchię wartości ${ }^{8}$. Nie można ignorować możliwości, które wiążą się z kulturą cyfrową, takich jak powstanie nowych areopagów dialogu, spotkań, wymiany myśli, dostępu do wiedzy i informacji, aktywizowania postaw obywatelskich i uczestnictwa w życiu społeczno-politycznym9 ${ }^{9}$. Oczywiście przestrzeń internetu to także wielkie zasoby treści i pomocy katechetycznych ${ }^{10}$. Jak zaznaczają autorzy

\footnotetext{
3 Adrian Galbas, Epidemia ujawniła braki w katechezie dzieci i młodzieży, w: https://ekai.pl/bp-adrian-galbas-sac-epidemia-ujawnila-braki-w-katechezie-doroslych-i-mlodziezy/ [dostęp 25.09.2020].

4 Franciszek, Adhortacja apostolska Evangelii gaudium o głoszeniu Ewangelii w świecie współczesnym, tekst polski, Częstochowa 2014, 33.

5 Papieska Rada ds. Krzewienia Nowej Ewangelizacji, Dyrektorium o katechizacji, tekst polski, Kielce 2020.

6 Zob. Kongregacja ds. Duchowieństwa, Dyrektorium ogólne o katechizacji, tekst polski, Poznań 1998 (dalej: DK).

7 Zob. DK 359-372.

8 DK 359.

9 Zob. DK 360, por. Franciszek, Adhortacja apostolska Christus vivit do młodych i całego Ludu Bożego, tekst polski, Częstochowa 2018, (dalej: CV), 87.

10 Zob. T. Kopiczko, Nowe fora katechezy, „Studia Katechetyczne”, t. 13 (2017), s. 177.
} 
Dyrektorium...: „Pod wieloma względami można mówić o pozytywnym cyfrowym wzmocnieniu"11 a więc o wyjątkowej użyteczności technologii cyfrowych w edukacji, świadomości czy jakości życia człowieka. Obok niezaprzeczalnych zalet kultury cyfrowej trzeba wspomnieć również o niebezpieczeństwach, które są z nią związane. Środowisko cyfrowe może stać się bowiem przestrzenią samotności, manipulacji, wyzysku czy cyberprzemocy. Zbytnie zakorzenienie w wirtualnym świecie może wiązać się z uzależnieniem, izolacją, utratą kontaktu z rzeczywistością, a więc $\mathrm{z}$ pewną ewakuacją z realnego świata i osobowych relacji ${ }^{12}$.

Już w odniesieniu do dzieci w dokumencie podkreślono, że znaczna część z nich to "cyfrowi tubylcy”, co skutkuje zmianami zarówno „w zakresie poznawczym i relacjonalnym w młodych pokoleniach, oddziałując również w jakiś sposób na naturalną skłonność do doświadczenia religijnego"13. Świadomość tę wyrażono także przy programowaniu katechezy i szkolnego nauczania religii w Polsce podkreślając, iż w klasach 1-4 szkoły podstawowej „dzieci często i chętnie używają telefonów komórkowych, bardziej nawet do zabawy niż do komunikacji z innymi. Na ogół bez problemów radzą sobie z obsługą większości urządzeń multimedialnych"14. Z wiekiem jednak ten sposób wykorzystania nowoczesnych technologii ulega zmianie i urządzenia służą nie tylko rozrywce czy zdobywaniu informacji, ale równie często umożliwiają kontakt $\mathrm{z}$ innymi ${ }^{15}$. $\mathrm{Z}$ tej racji uczniowie są niemal bezustannie „zalogowani” czy „on-line”, stając się użytkownikami coraz nowszych komunikatorów lub serwisów społecznościowych - nierzadko korzystając z nich wbrew regulaminowi, który zezwala na zakładanie kont osobom starszym (np. od 13. roku życia).

To sprawia, że nauczanie religii w szkole podstawowej w rzeczywistości cyfrowej wiąże się z dodatkowymi trudnościami czy wyzwaniami. Nie dotyczą one jedynie kwestii metodycznych, choć w myśl zasady wierności Bogu i człowiekowi słuszne jest zaznajamianie się z tym, co bliskie uczniom i czym oni żyją. We wskazaniach do realizacji programu nauczania religii w szkole podstawowej nie brakuje zatem zachęt do prowadzenia zajęć $\mathrm{z}$ tablicą interaktywną, jak również „zastosowania metod $\mathrm{z}$ wykorzystaniem nowoczesnych środków dydaktycznych związanych z komputerem i powiązanymi z nim elektronicznymi urządzeniami, aby trafiać do uczniów zarówno słowem, dźwiękiem, jak obrazem" ${ }^{\prime 16}$. W czasie zdalnego nauczania prowadzonego w szkołach od 12 marca 2020 roku katecheci zapoznali się z wieloma platformami i aplikacjami umożliwiającymi przekaz treści

\footnotetext{
11 DK 360.

12 Zob. DK 361, por. CV 88-89.

13 DK 237.

14 Konferencja Episkopatu Polski, Podstawa programowa katechezy Kościoła katolickiego w Polsce, Częstochowa 2018 (dalej: PPK), s. 29.

15 Zob. A. Wrońska, R. Lange, Nastolatek jako użytkownik Internetu - społeczny wzorzec konsumpcji, w: Nastolatki wobec Internetu, red. M. Tanaś, Warszawa 2016, s. 16.

16 PNR, s. 78.
} 
czy kształtowanie umiejętności z wykorzystaniem narzędzi cyfrowych. Wzrosła liczba pomocy opracowanych z wykorzystaniem Genial.ly, Learning Apps, eTwinning, Padlet czy innych rozwiązań. Znacznie częściej zaczęto odwiedzać portale związane z wydawnictwami katechetycznymi odpowiedzialnymi za serie podręczników. Katecheci zaczęli nagrywać własne filmiki na YouTubie lub udostępniać materiały przygotowane przez innych. W ślad za komunikatem Komisji Wychowania Katolickiego w sprawie zdalnego nauczania diecezjalne referaty katechetyczne zamieszczały wykazy mediów pomocnych w kształceniu na odległość. Mimo zachęt do uwspółcześniania przekazu nieustannie przypominano, że choć nowoczesne technologie są szansą na wzbogacenie tradycyjnych sposobów formacji chrześcijańskiej, to jednak „rodzą nowe wyzwania związane z wychowaniem uczniów do odpowiedzialnego korzystania $\mathrm{z}$ nich" ${ }^{\text {"17 }}$. Z kolei katecheci - choć rozwinęli swe umiejętności techniczne - podkreślali, iż zdalne nauczanie umożliwiło przekaz treści, jednak pozostawiało wiele do życzenia w aspekcie wychowawczym czy jakże ważnym w nauczaniu religii - inicjacyjnym.

W kontekście kultury cyfrowej, niezależnie od tego, czy nauczanie odbywa się w sposób zdalny, czy tradycyjny, warto zachęcać katechetów do swoistego „rachunku sumienia” - refleksji nad uwzględnieniem nowoczesnych zagrożeń w przekazie treści religijnych i kształtowaniu postaw. Korzystanie z internetu przez dzieci rodzi wieloaspektowe konsekwencje - z jednej strony więc może szkodzić im samym, prowadząc do pogorszenia stanu zdrowia. $Z$ drugiej - może negatywnie wpływać na relacje z innymi - zarówno rówieśnikami, którzy nie tak rzadko padają ofiarami hejtu w sieci, jak i z rodzicami, którzy kierują nakazy i zakazy zmuszające do „bycia off-line” czy odłożenia sprzętów na rzecz wykonania obowiązków. Wreszcie zanurzenie $\mathrm{w}$ wirtualnej rzeczywistości w realny sposób wpływa na relację z Bogiem i kondycję moralną dzieci, które nie zawsze są świadome tego, że w cyfrowym świecie nie przestają obowiązywać Boże przykazania, a obecność w sieci stanowi okazję do świadectwa chrześcijańskiego ${ }^{18}$.

Wprawdzie dla niektórych dzieci internet i aktywność w wirtualnej przestrzeni stwarzają okazję do ukazania swego innego oblicza - tak może być w przypadku niektórych dzieci ze spektrum autyzmu, wykazujących trudności w kontaktach społecznych. Mogą one kompensować niejako swe trudności za pośrednictwem narzędzi cyfrowych i wirtualnej przestrzeni, która pozwala im na pewną anonimowość, oferując przy tym możliwość podzielenia się zainteresowaniami, wykazania

\footnotetext{
17 PNR, s. 154.

18 Próbę uświadamiania tego dzieciom A. Rayzacher-Majewska podejmowała w ramach warszawskiego XXII Festiwalu Nauki w 2019 roku, poprzez spotkania nt. „DEKALOGowanie - o właściwym wykorzystywaniu Internetu, zgodnie z Bożymi Przykazaniami” (https://uksw.edu.pl/pl/uniwersytet/ uczelnia-dzis/aktualnosci/1488-xxii-festiwal-nauki), a także z racji obchodów Bezpiecznego Dnia Internetu, w ramach którego studenci z Koła Naukowego Katechetyków UKSW opracowali pod jej kierunkiem konspekty religii dla uczniów szkoły podstawowej klas 1-4 „Boże dzieci w sieci” oraz dla klas 5-8 „DEKALOGowanie” (http://knk.kolanaukowe.uksw.edu.pl/).
} 
talentem, co w relacjach „na żywo” nie jest łatwe. Twierdzi się wręcz, iż „w długiej perspektywie czasu pełne wykorzystanie potencjału e-technologii w edukacji może przełożyć się na zwiększenie szansy dzieci dotkniętych autyzmem na samodzielne dorosłe życie"19. Nie zmienia to jednak faktu, iż w przypadku reszty dzieci funkcjonowanie $w$ wirtualnej przestrzeni odzwierciedla ich zachowania i postawy przyjmowane w rzeczywistych środowiskach - uczniowie twórczy tworzą i udostępniają swe dzieła w sieci, uczniowie lubiący sport wykorzystują internet do poznawania ulubionej dyscypliny i jej przedstawicieli, jak również sprawcami cyberbullingu byli ci, którzy dopuszczali się przemocy wobec rówieśników w szkole czy na podwórku ${ }^{20}$.

Dwa pierwsze etapy edukacyjne przypadające na czas nauki w szkole podstawowej obfitują w możliwości katechetycznego przygotowania uczniów do funkcjonowania w cyfrowym świecie. Wyrazem tego jest podkreślana każdorazowo $\mathrm{w}$ dokumentach programowych korelacja religii z edukacją szkolną. Nie zabrakło jej również w wytycznych zawartych w Podstawie programowej katechezy Kościoła katolickiego $w$ Polsce z 2018 roku. W odniesieniu do pierwszego etapu edukacyjnego obejmującego klasy 1-4 szkoły podstawowej korelacja z edukacją informatyczną (klasy 1-3) oraz z informatyką (klasa 4) winna dotyczyć właściwego korzystania z narzędzi i mediów elektronicznych oraz przestrzegania prawa i bezpieczeństwa $\mathrm{w}$ sieci $^{21}$. Choć na kolejnych etapach edukacyjnych korelacja religii $\mathrm{z}$ informatyką nie jest wprost wyrażona w dokumentach programowych, to świadomość funkcjonowania uczniów w sieci zobowiązuje katechetów do tego, by np. omawiając Dekalog czy przykazanie miłości Boga i bliźniego, zwracali uwagę na ich aktualność w przestrzeni wirtualnej. Gdy z kolei mowa o świętych lub współczesnych świadkach wiary, warto zaprezentować postać św. Izydora uznawanego za patrona internautów, jak również nastoletniego programisty - Carlo Acutisa, którego beatyfikację zapowiedziano na 10 października 2020 roku.

Nauczanie religii w szkole podstawowej to również doskonała okazja do przedstawienia dzieciom licznych katolickich stron internetowych, portali i innych źródeł elektronicznych, z pomocą których mogą one wzbogacać swoją znajomość treści religijnych. Na szczególną uwagę zasługują strony i aplikacje umożliwiające poznawanie tekstu biblijnego bądź czytań liturgicznych. Dodatkową atrakcją dla uczniów może być wprowadzenie elementu rywalizacji, jak ma to miejsce na platformie gamifikacyjnej „Strażnicy Słowa”. Wreszcie internet stanowi obszerne źródło wiedzy o zgromadzeniach zakonnych oraz instytucjach religijnych, charytatywnych i misyjnych, z którymi uczniowie mogliby współpracować. Interesującą propozycją

\footnotetext{
19 A. Landowska i in., E-technologie w edukacji i terapii dzieci z autyzmem w Polsce, „EduAkcja. Magazyn edukacji elektronicznej” 2(2014), s. 47.

20 Zob. J. Pyżalski, Od paradygmatu ryzyka do paradygmatu szans: prorozwojowe i prospołeczne używanie Internetu przez dzieci i młodzież, w: Nastolatki wobec Internetu, red. M. Tanaś, Warszawa 2016, s. 58.

21 Zob. PPK s. 48.
} 
jest wzbogacanie lekcji religii poprzez odsyłanie uczniów do stron internetowych czasopism katolickich.

Już od najmłodszych lat należy przygotowywać uczniów do właściwego korzystania z mediów i odpowiedzialnego funkcjonowania w sieci. Swoista edukacja medialna - choć nie jest oferowana jako osobny przedmiot - winna w miarę możliwości dokonywać się w szkole na rożnych przedmiotach, także na religii. Szczególnie, że religia w tym względzie oferuje perspektywy, którymi nie dysponuje żaden inny przedmiot - owo odpowiedzialne funkcjonowanie w cyberprzestrzeni osadza w kontekście relacji z ludźmi i z Bogiem, nadając im tym samym wymiar aksjologiczny, moralny czy wręcz religijny. Właściwa formacja religijna obejmująca również rzeczywistość wirtualną winna zatem być realizowana przez cały czas edukacji w szkole podstawowej, ale na nim nie poprzestawać. Klasy VI-VIII to zgodnie z założeniami programowymi - czas przygotowania do bierzmowania. Bierzmowany zaś winien z większą świadomością i odpowiedzialnością przeżywać swą tożsamość chrześcijańską nie tylko poprzez świadectwo, ale także aktywne włączenie w dzieło szeroko rozumianej ewangelizacji.

W kontekście katechetycznym ważne jest, aby w obliczu wszechobecnych technologii cyfrowych nie stracić osobowego charakteru relacji i spotkania, który jest niezbędny dla prawdziwej ewangelizacji. „W procesie głoszenia Ewangelii najważniejszym pytaniem nie jest to, jak posługiwać się nowymi technologiami dla celów ewangelizacyjnych, ale jak stać się ewangelizująca obecnościa na cyfrowym kontynencie"22. Istotna jest ta szersza perspektywa, aby obecności w kulturze cyfrowej i korzystania z niej w praktyce katechetycznej nie sprowadzać tylko do kwestii technicznych (jak to zrobić?), ale żeby poddawać refleksji również kwestie ogólniejsze i bardziej fundamentalne (jak zachować proporcje między zanurzeniem się w kulturę cyfrową a obecnością w świecie realnym?, jak, będąc obecnym w świecie cyfrowym, pomagać naszym katechizowanym w „kwarantannie” opuszczania wirtualnej przestrzeni na rzecz realnego zaangażowania?). W innym miejscu dokumentu autorzy zaznaczają, że współcześni nastolatkowie, mimo technologicznego obycia, nie są przygotowani do zmierzenia się ze wszystkimi wyzwaniami społeczeństwa cyfrowego, co powoduje pilną konieczność rzetelnej edukacji medialnej ${ }^{23}$.

Kwestie związane z kulturą cyfrową podjęte są także przy okazji omawiania metodologii w katechezie. Nie można ignorować faktu, że dla wielu ludzi, zwłaszcza młodych, przestrzeń wirtualna jest nie mniej ważna od świata realnego, ponieważ niezrozumienie tej sytuacji „może skutkować pozostaniem poza orbitą zainteresowań wielu ludzi”24. Walorem cyfrowych form komunikacji jest niewątpliwie ich otwartość na interakcję, a zatem możliwość lepszej komunikacji z katechizowanymi, co możliwe jest dzięki znajomości jej skutecznych mechanizmów,

\footnotetext{
22 DK 371.

23 DK 368

24 DK 213.
} 
a także dzięki takiej obecności w sieci, która będzie świadectwem wiary i wartości ewangelicznych ${ }^{25}$. Rzeczywistość wirtualna ma być jednak jedynie pomocą, środkiem do bezpośredniego spotkania osób, które jest warunkiem rzeczywistości duchowej, sakramentalnej i kościelnej ${ }^{26}$.

Nauczanie religii w szkole ponadpodstawowej analogicznie, jak w poprzednich etapach edukacyjnych, zaprogramowane jest przez zapisy Podstawy programowej katechezy Kościoła katolickiego w Polsce ${ }^{27}$, która po ostatniej reformie systemu szkolnego w Polsce doczekała się już trzeciej odsłony. Obok celów, treści, wymagań, oczekiwanych postaw, które prezentuje dokument, znajdują się w nim również „zalecane warunki i sposoby realizacji”" Właśnie w tym krótkim, opisowym zwróceniu uwagi na kwestie metodyczne można dostrzec zachętę i wskazania również do korzystania z technologii cyfrowych. Wśród zawartych wskazań i inspiracji pojawia się postulat „towarzyszenia młodzieży w odkrywaniu powołania chrześcijańskiego"29. Towarzyszenie to rodzaj dyskretnej obecności, wskazywania, dawania pewnych podpowiedzi przy uszanowaniu wolności i autonomii katechizowanego. Oczywiście chodzi tu o obecność w szkole bądź poza jej murami, czas na rozmowę czy umiejętność odpowiedzi na pytania katechizowanych, ale biorąc pod uwagę dzisiejsze możliwości, możemy odczytać tu również zachętę do obecności w sieci, choćby na forach społecznościowych, która właśnie poprzez zamieszczanie wartościowych postów, linkowanie ciekawych artykułów czy multimediów, zapraszanie do lektury ciekawych stron internetowych, gotowość do odpowiedzi na nurtujące uczniów pytania będzie takim właśnie towarzyszeniem ${ }^{30}$.

Ponieważ katecheza ma pomagać w coraz dojrzalszym wyznaniu wiary oraz włączać w Kościół, na etapie nauczania młodzieży w szkołach ponadpodstawowych niezbędne jest kształtowanie świadomości sakramentalnej, która przekładać się będzie na codzienne życie i praktykowanie wiary ${ }^{31}$. W realizacji powyższych wskazań może również pomóc bogactwo internetu, gdy obok realizowanych lekcji (bądź w ich trakcie) zaproponujemy uczniom przeczytanie ciekawego artykułu, wysłuchanie czy obejrzenie świadectwa albo lekturę bloga, na którym autor dzieli się swoim przeżywaniem wiary. Oczywiście przykładów takich materiałów jest wiele, ważne jest to, aby były one pod każdym względem wiarygodne, a więc zarówno od strony osoby, która je prowadzi, jak i od strony edytorskiej czy technicznej ${ }^{32}$.

\footnotetext{
${ }^{25}$ Zob. DK 214.

26 Zob. DK 217.

27 Konferencja Episkopatu Polski, Podstawa programowa katechezy..., dz. cyt. (PPK).

28 Dla nauczania religii szkół ponadpodstawowych: PPK, s. 123-125.

29 PPK, s. 123.

${ }^{30}$ Na temat możliwości i owocności obecności katechety w internecie zobacz: D. Wyżkiewicz,

D. Gospodarek, Ostatni dzwonek. Rozmowy o przyszłości lekcji religii, Warszawa 2020, s. 33-36.

31 Zob. PPK, s. 124.

32 Jako ilustrację proponujemy zapoznanie się z blogiem dziennikarki Katarzyny Olubińskiej: http://bogwwielkimmiescie.pl.
} 
Zasoby internetu to wymarzona przestrzeń do stosowania zalecanych na tym etapie edukacyjnym metod poszukujących ${ }^{33}$. Dla wielu nastolatków zaskoczeniem może być to, że na stronach internetowych znajdziemy Pismo Święte, dokumenty Kościoła, albo to, że swoją oficjalną stronę ma chociażby Stolica Apostolska ${ }^{34}$ czy Konferencja Episkopatu Polski ${ }^{35}$.

Kolejną przestrzenią, w której można obficie czerpać $\mathrm{z}$ technologii cyfrowych, jest postulat rozwijania w uczniach umiejętności samokształcenia i osobistego samodzielnego poszukiwania odpowiedzi na pojawiające się w ich życiu pytania i problemy. „Z uwagi na aktywność młodzieży w cyberprzestrzeni warto wskazywać na powyższe źródła treści religijnych w internecie, jak również na wartościowe strony i portale katolickie ${ }^{36}$. Jednocześnie należy uwrażliwiać katechizowanych na realne zagrożenia - również duchowe - wirtualnego świata" ${ }^{\text {"37 }}$. Wartość poznawcza internetu wymaga jednak przewodnika, który pomoże odnaleźć się w gąszczu stron, linków i portali, ale także pomoże umiejętnie ocenić ich wiarygodność, przecież bardzo różną. To ostatnie ze wskazań Podstawy... koresponduje ze wspomnianą przez Dyrektorium... koniecznością edukacji medialnej, o której była już mowa przy okazji edukacji religijnej na poprzednich etapach edukacyjnych.

Wracając do refleksji księdza, nauczyciela religii, wyrażonej niedługo po wybuchu epidemii, można rozszerzyć jego myśli. Świat technologii cyfrowych czy - jak definiują autorzy odnowionego Dyrektorium... - kultura cyfrowa to dzisiaj oczywistość, zwłaszcza naszych nastoletnich katechizowanych. Trzeba umieć odnaleźć się w tej rzeczywistości (niezależnie od pandemii i warunków nauczania), trzeba w niej jakoś funkcjonować. I to najlepiej tak, żeby zbliżało to ludzi do siebie, a także żeby i nauczycieli religii, i uczniów powierzonych ich pieczy zbliżało to do Boga ${ }^{38}$. Ta akurat relacja, nazywana niekiedy wertykalną, wymyka się wszelkim, nawet najlepszym i najnowocześniejszym środkom komunikowania, które koncentrują się raczej wokół wymiaru horyzontalnego ${ }^{39}$.

Jak przypomniał papież Jan Paweł II, „Od czasów gdy Apostołowie nauczali ustnie, a w Kościołach odczytywano listy, aż do czasów dzisiejszych wyposażonych we wszelkiego rodzaju pomoce, katecheza pobudzana przez Pasterzy i przy współudziale wspólnot zawsze szukała dróg i środków najbardziej odpowiednich dla wypełnienia swej misji” ${ }^{40}$. Niewątpliwie takimi środkami dziś są środki społecznego przekazu, a drogi szeroko rozumianej katechezy wiodą także przez cyfrowy kontynent. Nie ulega zatem wątpliwości, iż konieczne jest posługiwanie się nowymi

\footnotetext{
33 Zob. PPK, s. 124.

${ }^{34}$ http://www.vatican.va/content/vatican/en.html

${ }^{35} \mathrm{http}: / /$ www.episkopat.pl

36 Zob. Mariusz Śliwa, E-katecheza?..., dz. cyt.

37 Zob. PPK, s. 125.

38 Por. Mariusz Śliwa, E-katecheza?..., dz. cyt.

39 Zob. T. Kopiczko, Nowe fora..., dz. cyt., s. 178-179.

${ }^{40}$ CT 46
} 
technologiami w nauczaniu religii, co zresztą jest postulowane już od wielu lat ${ }^{41}$. Zamiast więc pytać: „Czy korzystać z dóbr kultury cyfrowej?”, należałoby raczej zastanawiać się: „Jak z nich korzystać?”.

Nie ulega wątpliwości, że dzisiejsze dzieci i młodzież znaczną część czasu spędzają na cyfrowym kontynencie. Kontynent ten - jak każdy inny - nie jest wolny od zagrożeń, zatem odpowiedzialny wychowawca podąży za swoimi wychowankami i zechce być tam, gdzie oni. Szczególnie, iż rażącym zaniedbaniem byłoby nie pójść tam w ślad za młodymi - wszak mając „łowić ludzi”, Boży rybacy winni zarzucać sieci tam, gdzie połów może być obfity. Znacznie łatwiej spotkać dziś niektórych młodych na Messengerze niż w kościele - a przecież podobnie jak ich praktykujący rówieśnicy oni także mają wiele pytań, również tych związanych z wiarą i życiem.

Kultura cyfrowa jest wytworem człowieka i już samo to predestynuje ją do bycia w kręgu zainteresowania katechezy, szczególnie nastawionej antropologicznie. Skoro punktem wyjścia ma być człowiek i jego sprawy, z powodzeniem można szukać ich w wirtualnej przestrzeni, jak najbardziej realnie oddającej problemy katechizowanych - ich radości i troski. Co więcej, „sieci społecznościowe karmią się [więc] pragnieniami zakorzenionymi w sercu człowieka" ${ }^{42}$ - skoro więc katecheta chciałby poznać te pragnienia, może szukać ich właśnie w sieci. Warto, by również stał się swoistym przewodnikiem po wirtualnym świecie, skoro tam „samozwańczy specjaliści wypowiadają się w kwestiach wiary i moralności nawet jeśli nie mają do tego żadnych kompetencji. Jakże więc istotne jest, by Kościół ze swej strony poprzez swych przedstawicieli zapewnił wiernym dostęp do rzetelnej wiedzy i prawdziwych informacji”"

Korzystając z bogactwa narzędzi cyfrowych należy pamiętać, iż wciąż pozostają one środkiem czy metodą - nie można zatem przyznać im pierwszoplanowej roli w procesie dydaktycznym. Są one w służbie katechezie i katechizowanemu, konieczne jest więc ich dostosowanie do celów, treści i odbiorcy. O takim dostosowaniu zazwyczaj można mówić w przypadku materiałów multimedialnych (lub nawet:

\footnotetext{
41 Najstarszy artykuł odnotowany w Bibliografii katechetycznej 1945-1995 nt. środków przekazu to tekst B. Jabłońskiej z 1960 roku nt. Lekcji ekranu. Zob. Bibliografia katechetyczna 1945-1995, oprac. R. Murawski, R. Czekalski, J. Tochmański, Warszawa 1999, s. 276. Doskonałą ilustracją rozwoju refleksji nad zastosowaniem środków przekazu i pomocy audiowizualnych w katechezie jest choćby zestawienie liczby artykułów poświęconych tym zagadnieniom w Bibliografii katechetycznej z trzech przedziałów czasowych (w nawiasach podano lata, których dotyczy dany tom bibliografii). Artykuły nt. środków społecznego przekazu: 47 (1945-1995); 16 (1996-2000); 79 (2001-2010). Artykuły nt. środków audiowizualnych w katechezie: 56 (1945-1995); 14 (1996-2000); 40 (2001-2010). Można spodziewać się, iż w latach 2010-2020 tematyka ta była jeszcze bardziej popularna niż w ostatnim wskazanym okresie.

42 Benedykt XVI, Portale społecznościowe: bramy prawdy i wiary; nowe przestrzenie dla ewangelizacji. Orędzie na 47. Światowy Dzień Środków Społecznego Przekazu, w: https://www.paulus.org.pl/220,47-sdssp-benedykt-xvi-2013 [dostęp 4.10.2020].

43 A. Rayzacher-Majewska, Z Dobrą Nowina wśród „tweetów” i „lajków”, „Warszawskie Studia Pastoralne" 2(2014), s. 118 (107-120).
} 
hipermedialnych ${ }^{44}$ ) zawartych czy proponowanych przez serie podręczników do religii. Jednocześnie samo zaproponowanie albo wskazanie nowoczesnej technologii nie gwarantuje skuteczności przekazu, jeśli katecheta nie będzie wyposażony we właściwe umiejętności i kompetencje. Przypomina o tym ks. A. Bielinowicz, podkreślając, iż „współczesny nauczyciel powinien umieć posługiwać się komputerem i znać możliwości, które dają technologie informatyczne, tak jak zna podręczniki i pomoce dydaktyczne wykorzystywane na co dzień" ${ }^{45}$.

Nade wszystko jednak w nauczaniu religii w cyfrowym świecie należy pamiętać, iż celem nadrzędnym katechezy niezmiennie pozostaje doprowadzenie uczniów do zjednoczenia z Jezusem i głębokiej z Nim zażyłości ${ }^{46}$. Aby ten cel był w pełni zrealizowany, na pewnym etapie konieczne będzie przejście z wirtualnego świata do rzeczywistości. Internet może pomóc w pouczeniu o Jezusie i Jego orędziu. Może być pomocny w egzystencjalnej interpretacji orędzia, zapoznawaniu z dzisiejszym świadkami wiary i kształtowaniu postaw. Pozostaje jednak bezradny wobec chrześcijańskiego wtajemniczenia, do którego potrzebne jest osobiste i realne spotkanie. Mimo niezaprzeczalnych wartości świat cyfrowy nie umożliwi uczniom inicjacji chrześcijańskiej. Doceniając więc walory przestrzeni wirtualnej, należy nieustannie podkreślać jej ograniczoność w katechetycznej posłudze Słowa i zachęcać uczniów do „wylogowania” na rzecz spotkania z Jezusem w modlitwie i sakramentach.

\section{Streszczenie}

W artykule zaprezentowano zagadnienie nauczania religii w szkołach podstawowych oraz średnich w kontekście kultury cyfrowej. W refleksji uwzględniono zdalne nauczanie, prowadzone w polskich szkołach od marca do czerwca $2020 \mathrm{w}$ związku z epidemią COVID-19. Autorzy przypomnieli racje, dla których warto uwzględniać nowoczesne technologie w nauczaniu religii na różnych etapach edukacyjnych. Zawarli także praktyczne wskazówki do zastosowania technologii informacyjno-komunikacyjnych na lekcjach religii i uwzględnienia bogactwa internetu w procesie dydaktycznym. Odnosząc się do nauczania Kościoła, w tym najnowszych dokumentów katechetycznych, podkreślili szanse, jakie rzeczywistość cyfrowa oferuje działalności katechetycznej. Zwrócili także uwagę na niebezpieczeństwa związane z przebywaniem dzieci i młodzieży w sieci, i wyzwania, jakie w związku z tym stoją dziś przed katechetami.

Słowa kluczowe: nauczanie religii, katecheza, lekcje religii, zdalne nauczanie, kultura cyfrowa, rzeczywistość cyfrowa.

\footnotetext{
44 Zob. K. Mielnicki, Od fotografii do smartfona na lekcji religii, Lublin 2020, s. 105.

45 A. Bielinowicz, Rozwój kompetencji informatycznych nauczycieli religii w archidiecezji warmińskiej, Olsztyn 2020, s. 90.

46 Zob. CT 5.
} 


\section{RELIGIOUS EDUCATION IN THE SCHOOL TOWARDS DIGITAL REALITY}

\section{Summary}

The article presents the issue of teaching religion in primary and secondary schools in the context of digital culture. The reflection takes into account distance learning conducted in Polish schools from March to June 2020 in connection with the COVID-19 epidemic. The authors recalled the reasons why it is worth considering modern technologies in teaching religion at various educational stages. They also provided practical tips on the use of information and communication technologies in religion lessons and the incorporation of the richness of the Internet in the teaching process. Referring to the teaching of the Church, including the latest catechetical documents, they emphasized the opportunities that digital reality offers to catechetical activity. They also drew attention to the dangers related to the presence of children and young people on the Internet and the challenges that face catechists today.

Keywords: teaching religion, catechesis, religion lessons, remote teaching, digital culture, digital reality.

\section{Bibliografia}

Benedykt XVI, Portale społecznościowe: bramy prawdy i wiary; nowe przestrzenie dla ewangelizacji. Orędzie na 47. Światowy Dzień Środków Społecznego Przekazu, w: https:// www.paulus.org.pl/220,47-sdssp-benedykt-xvi-2013 [dostęp 4.10.2020].

Bielinowicz A., Rozwój kompetencji informatycznych nauczycieli religii $w$ archidiecezji warmińskiej, Olsztyn 2020.

Franciszek, Adhortacja apostolska Christus vivit do młodych i całego Ludu Bożego, tekst polski, Częstochowa 2018.

Franciszek, Adhortacja apostolska „Evangelii gaudium” o głoszeniu Ewangelii w świecie współczesnym, tekst polski, Częstochowa 2014.

Galbas A., Epidemia ujawniła braki w katechezie dzieci i młodzieży, w: https://ekai.pl/ bp-adrian-galbas-sac-epidemia-ujawnila-braki-w-katechezie-doroslych-i-mlodziezy/ [dostęp 25.09.2020].

Komisja Wychowania Katolickiego Konferencji Episkopatu Polski, Program nauczania religii rzymskokatolickiej w przedszkolach i szkołach, Częstochowa 2019.

Konferencja Episkopatu Polski, Podstawa programowa katechezy Kościoła katolickiego w Polsce, Częstochowa 2018.

Kongregacja ds. Duchowieństwa, Dyrektorium ogólne o katechizacji, tekst polski, Poznań 1998,

Kopiczko T., Nowe fora katechezy, „Studia Katechetyczne”, t. 13 (2017).

Landowska A. i in., E-technologie w edukacji i terapii dzieci zautyzmem w Polsce, „EduAkcja. Magazyn edukacji elektronicznej" 2(2014), s. 42-48.

Mielnicki K., Od fotografii do smartfona na lekcji religii, Lublin 2020.

Murawski R., Czekalski R., Tochmański J., Bibliografia katechetyczna 1945-1995, oprac. Warszawa 1999. 
Papieska Rada ds. Krzewienia Nowej Ewangelizacji, Dyrektorium o katechizacji, tekst polski, Kielce 2020.

Poleszak W., Pyżalski J., Psychologiczna sytuacja dzieci i młodzieży w dobie pandemii, w: Edukacja w czasach pandemii wirusa COVID-19. Z dystansem o tym, co robimy obecnie jako nauczyciele, red. J. Pyżalski, Warszawa 2020.

Pyżalski J., Od paradygmatu ryzyka do paradygmatu szans: prorozwojowe i prospołeczne u̇̇ywanie Internetu przez dzieci i młodzież, w: Nastolatki wobec Internetu, red. M. Tanaś, Warszawa 2016, s. 55-62

Rayzacher-Majewska A., Z Dobra Nowina wśród „tweetów” i „lajków”, „Warszawskie Studia Pastoralne" 2(2014), s. 107-120.

Śliwa M., E-katecheza? Zdalna katecheza w czasach \#zostańcie w domu, w: https://przemyska.pl/2020/03/19/katecheza-on-line/ [plik do pobrania, dostęp: 25.09.2020].

Wrońska A., Lange R., Nastolatek jako użytkownik Internetu - społeczny wzorzec konsumpcji, w: Nastolatki wobec Internetu, red. M. Tanaś, Warszawa 2016, s. 15-26.

Wyżkiewicz D., Gospodarek D., Ostatni dzwonek. Rozmowy o przyszłości lekcji religii, Warszawa 2020.

\section{O autorach}

ks. Radosław MAZUR - kapłan diecezji koszalińsko-kołobrzeskiej, adiunkt w katedrze Teologii Praktycznej Instytutu Nauk Teologicznych Uniwersytetu Szczecińskiego, wykładowca katechetyki w Wyższym Seminarium Duchownym i w Instytucie Teologicznym w Koszalinie, konsultor Komisji Wychowania Katolickiego KEP.

Aneta RAYZACHER-MAJEWSKA - dr teologii w zakresie katechetyki, adiunkt w Katedrze Katechetyki Fundamentalnej i Materialnej na Wydziale Teologicznym Uniwersytetu Kardynała Stefana Wyszyńskiego w Warszawie, konsultor Komisji Wychowania Katolickiego Konferencji Episkopatu Polski, rzeczoznawca ds. oceny programów nauczania religii i podręczników katechetycznych, przewodnicząca Komisji Rewizyjnej Stowarzyszenia Katechetyków Polskich, katechetka w przedszkolach, autorka materiałów katechetycznych, kierownik projektów „Katecheta człowiek z klasą” i „Katecheza bez granic”. 